\title{
Characterization of Epichloë coenophiala within the US: are all tall fescue endophytes created equal?
}

\author{
Carolyn A. Young ** , Nikki D. Charlton*, Johanna E. Takach, Ginger A. Swoboda, \\ Michael A. Trammell, David V. Huhman and Andrew A. Hopkins ${ }^{\dagger}$
}

The Samuel Roberts Noble Foundation, Forage Improvement Division, Ardmore, OK, USA

\section{Edited by:}

James Levi Klotz, United States Department of Agriculture -

Agricultural Research Service, USA

Reviewed by:

Joana Costa, Center for

Neuroscience and Cellular Biology,

Portugal

Charles Wilson Bacon, United

States Department of Agriculture, USA

*Correspondence:

Carolyn A. Young, The Samuel Roberts Noble Foundation, Forage Improvement Division, 2510 Sam Noble Parkway, Ardmore, OK 73401, USA

e-mail: cayoung@noble.org

${ }^{\dagger}$ Present address:

Andrew A. Hopkins, Dow

AgroSciences Inc., York, NE, USA

¥ These authors have contributed equally to this work.
Tall fescue (Lolium arundinaceum) is a valuable and broadly adapted forage grass that occupies approximately 14 million hectares across the United States. A native to Europe, tall fescue was likely introduced into the US around the late 1800's. Much of the success of tall fescue can be attributed to Epichloë coenophiala (formerly Neotyphodium coenophialum) a seed borne symbiont that aids in host persistence. Epichloë species are capable of producing a range of alkaloids (ergot alkaloids, indole-diterpenes, lolines, and peramine) that provide protection to the plant host from herbivory. Unfortunately, most tall fescue within the US, commonly referred to as "Kentucky-31" (KY31), harbors the endophyte $E$. coenophiala that causes toxicity to grazing livestock due to the production of ergot alkaloids. Molecular analyses of tall fescue endophytes have identified four independent associations, representing tall fescue with E. coenophiala, Epichloë sp. FaTG-2, Epichloë sp. FaTG-3, or Epichloë sp. FaTG-4. Each of these Epichloë species can be further distinguished based on genetic variation that equates to differences in the alkaloid gene loci. Tall fescue samples were evaluated using markers to simple sequence repeats (SSRs) and alkaloid biosynthesis genes to determine endophyte strain variation present within continental US. Samples represented seed and tillers from the Suiter farm (Menifee County, KY), which is considered the originating site of KY31, as well as plant samples collected from 14 states, breeder's seed and plant introduction lines (National Plant Germplasm System, NPGS). This study revealed two prominent E. coenophiala genotypes based on presence of alkaloid biosynthesis genes and SSR markers and provides insight into endophyte variation within continental US across historical and current tall fescue samples.

Keywords: Neotyphodium coenophialum, fescue toxicosis, ergot alkaloids, Kentucky-31 (KY31), endophyte diversity

\section{INTRODUCTION}

\section{HISTORY OF KY31 TALL FESCUE AND DISCOVERY OF ENDOPHYTE}

Tall fescue [Lolium arundinaceum (Schreb.) Darbysh. syn Festuca arundinaceae Shreb.] was introduced into the United States from Europe in the 1800's and is considered an important cool season perennial forage crop (Hoveland, 2009). Tall fescue is widely adapted to the eastern United States spanning 14 million hectares (35 million acres) with the fescue belt considered the major region of adaptation and use (Figure 1) (Ball et al., 1993). A timeline representing significant research events of tall fescue is shown in Figure 1 and outlined below.

One of the most well known tall fescue cultivars, "Kentucky31" (KY31), was collected in 1931 by Dr. E. N. Fergus (University of Kentucky) on a farm owned by William Suiter (Menifee County, KY) (Fergus and Buckner, 1972). KY31 gained wide acceptance as a grass with excellent agronomic attributes under difficult growth conditions, such as drought and poor soils. The KY31 ecotype was released in 1942, but was not officially registered as a cultivar until 1972 (Fergus and Buckner,
1972). Subsequently, the persistence and success of KY31 was attributed to the presence of the systemic fungal endophyte, Epichloë coenophiala. It was estimated that $90 \%$ of all tall fescue pastures in the US are endophyte infected (Siegel et al., 1985). The fitness benefits the endophyte provides include drought tolerance, improved competitive ability (Arachevaleta et al., 1989; West et al., 1993; Malinowski and Belesky, 2000), as well as protection from herbivores through the production of bioactive alkaloids (Clay et al., 1985; Bacon et al., 1986).

Unfortunately, although KY31 was known as a persistent cultivar, reports of poor animal performance when grazing this forage began in the 1940s (Cunningham, 1949; Jacobson et al., 1963). Animals that grazed on tall fescue suffered maladies such as fescue foot, fat necrosis, and fescue toxicosis (Bush et al., 1979). Cattle experiencing fescue toxicosis can exhibit rough hair coats, heat stress (wallowing in mud), elevated rectal temperatures, vasoconstriction, suppressed appetite, reduced prolactin levels, poor growth (lower average daily gains), and a reduction in calving rates (Hoveland et al., 1983; Hemken et al., 1984; 


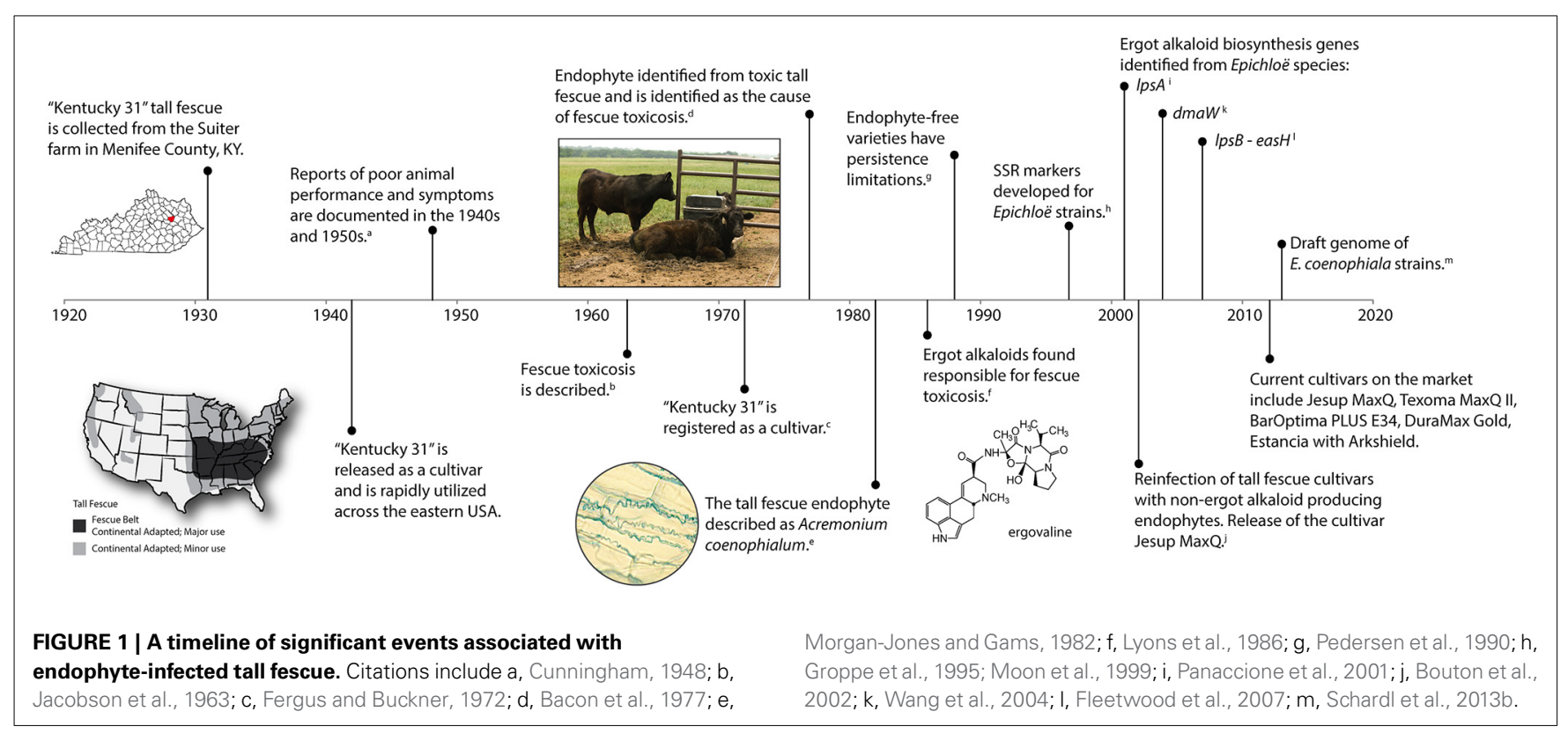

Stuedemann and Hoveland, 1988; Roberts and Andrae, 2004; Caldwell et al., 2013). Symptoms of fescue foot resembled those observed from ergot alkaloid toxicity seen with Claviceps purpurea on rye suggesting that an ergot alkaloid might be responsible for toxicity (Yates, 1971). However, although the syndrome was first described in 1963 (Jacobson et al., 1963) it took another decade before an endophyte was suggested as the causal agent. In 1977, a fungal endophyte was identified in toxic tall fescue as the likely culprit of these symptoms (Bacon et al., 1977), which was later confirmed by the production of ergot alkaloids by the fungus (Porter et al., 1979; Lyons et al., 1986; Bacon, 1988). The endophyte grows systemically through the upper plant parts and is maternally inherited in the seed (Siegel et al., 1984; Schardl, 2001).

\section{TALL FESCUE ENDOPHYTE DESCRIPTION}

Initially, Bacon et al. (1977) identified the tall fescue endophytes as E. typhina, which was later renamed Acremonium coenophialum to acknowledge the anomorphic state of Epichloë species (Morgan-Jones and Gams, 1982). Christensen and Latch (1991) described variation among isolates of A. coenophialum from tall fescue, and in 1993 the taxonomy of these endophytes was described (Christensen et al., 1993). The genus Acremonium was reclassified using phylogenetic analyses and A. coenophialum was renamed Neotyphodium coenophialum (Glenn et al., 1996). Finally, under the nomenclatural rule changes for fungi Neotyphodium is now included in the genus Epichloë resulting in the change to E. coenophiala (Leuchtmann et al., 2014). E. coenophiala is considered an asexual hybrid, phylogenetically described as a triparental hybrid with inferred ancestral progenitors from E. festucae, E. typhina subsp. poae, and the Lolium-associated endophyte (LAE) (Tsai et al., 1994; Moon et al., 2004).

E. coenophiala, like many Epichloë species, is capable of producing a variety of bioactive secondary metabolites. The four described classes of alkaloids produced by Epichloë species are ergot alkaloids, indole-diterpenes, lolines, and peramine (Siegel et al., 1990). Ergot alkaloids (e.g., ergovaline) and the indolediterpene, lolitrem $B$, have been shown to have anti-mammalian activity causing fescue toxicosis (Bacon et al., 1977) and ryegrass staggers (Fletcher and Harvey, 1981), respectively. Peramine is considered an insect feeding deterrent (Johnson et al., 1985; Rowan and Latch, 1994) and the lolines have been documented for their potent insecticidal activity (Bush et al., 1997). E. coenophiala as a species complex can produce all four classes of alkaloids (Table 1). However, the most commonly produced alkaloids are peramine, lolines, and ergovaline (Christensen et al., 1993; Leuchtmann et al., 2000; Schardl et al., 2013b).

Considerable research has been conducted to understand the biosynthesis of these bioactive compounds including identification and characterization of the gene products required for the biosynthesis of each alkaloid class (Panaccione et al., 2001; Wang et al., 2004; Spiering et al., 2005, 2008; Tanaka et al., 2005; Young et al., 2006, 2009; Fleetwood et al., 2007; Saikia et al., 2012; Pan et al., 2014). This has been supported with genome sequences, including draft genome sequences of three E. coenophiala strains (Schardl et al., 2013a,b). This research has provided an understanding of why Epichloë species can have diverse alkaloid profiles and provided the sequence to develop markers for mating type and key alkaloid biosynthesis genes to genetically evaluate endophyte diversity in planta (Charlton et al., 2012, 2014; Takach et al., 2012; Takach and Young, 2014).

To date, tall fescue is known to form associations with four taxonomic groups, E. coenophiala, Epichloë sp. FaTG-2, Epichloë sp. FaTG-3, and Epichloë sp. FaTG-4 that vary based on ploidy (either $2 \mathrm{x}$ or $3 \mathrm{x}$ ) and progenitors (Table 1). Initially tall fescue endophytes were distinguished by morphology and isozyme analysis to establish taxonomic groupings, and variation was also seen with the production of peramine, ergovaline, lolitrem $B$, and lolines (Christensen et al., 1993). Phylogenetic analyses were able 
Table 1 | Epichloë species and genotype variation associated with endophytes of tall fescue.

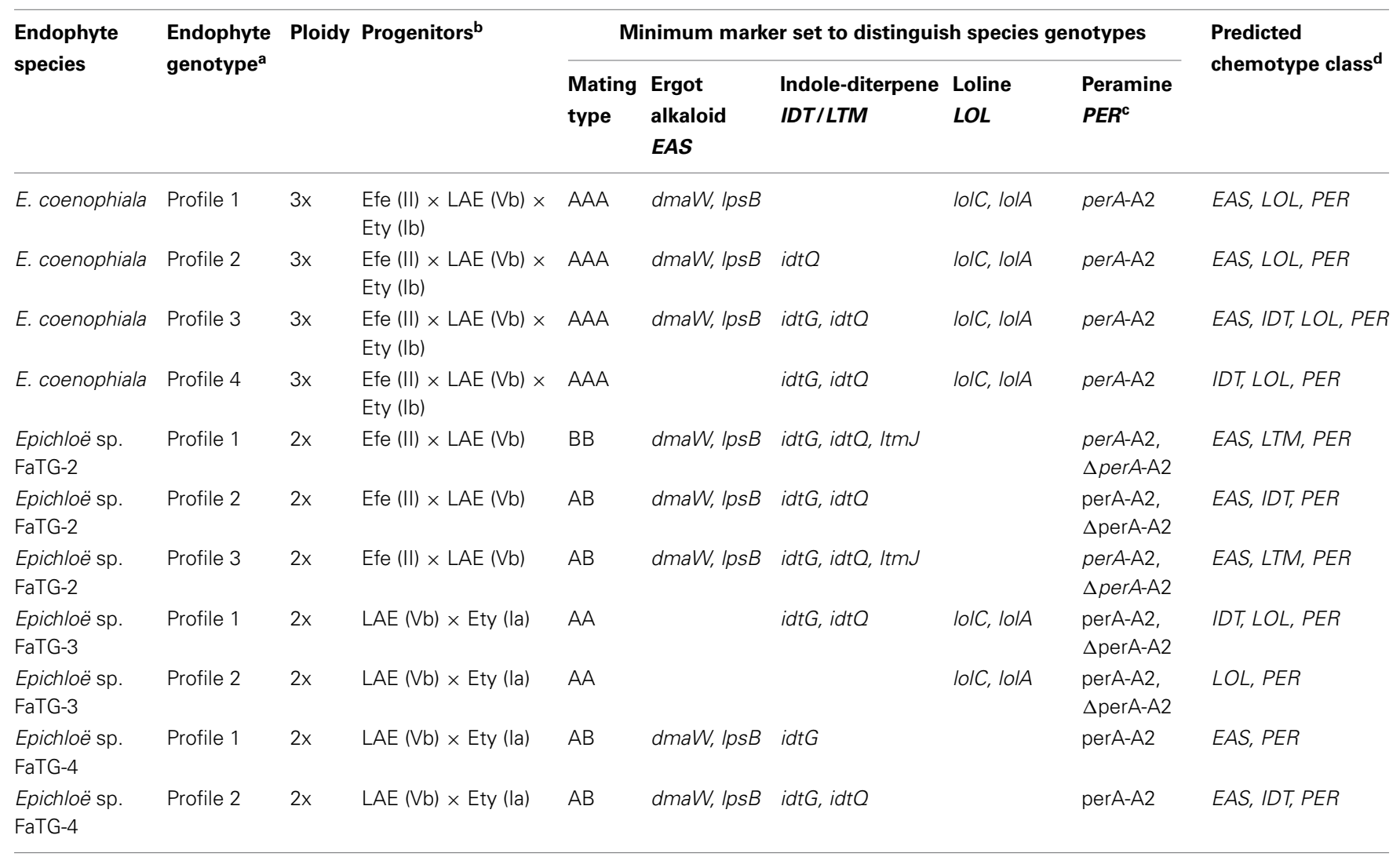

${ }^{a}$ Based on designations from Takach and Young (2014) and draft genome sequences of FaTG-2 isolates NFe45079 and NFe45115.

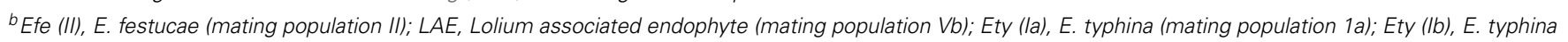
(mating population 1b); Mating population as designated from Leuchtmann et al. (2014).

${ }^{c}$ The perA-A2 marker is designed to the second adenylation domain. Some isolates have a deletion in this domain as represented by $\Delta$ perA-A2 (Takach et al., 2012).

¿Predicted chemotype class represents the class of genes that are found in the genome and do not always represent a functionally active locus. EAS, ergot alkaloids;

IDT, indole diterpenes; $L T M$, lolitrem $B$; $L O L$, lolines; PER, peramine.

to define the relationships of each taxonomic group to distinguish the ancestral progenitors of these hybrid species (Schardl et al., 1991, 2013b; Moon et al., 2004). The most studied of these species is E. coenophiala, the endophyte first identified in KY31.

Isozyme analyses of E. coenophiala isolates from within the US indicated that very little variation existed within this species (Leuchtmann and Clay, 1990). Although isozyme analysis can reflect endophyte diversity, this analysis requires pure cultures and thus is limited by the number of samples per tall fescue line that can be screened. Genetic analysis can now be performed directly with endophyte infected plant material using high throughput systems (Takach and Young, 2014). Markers have recently been used to determine the genetic diversity between tall fescue endophyte isolates and also evaluate their potential for alkaloid production (Ekanayake et al., 2012; Takach et al., 2012; Takach and Young, 2014). In fact, variation of mating type and alkaloid genes determined by PCR could be enough to allow placement of tall fescue endophytes into distinct genotype groups associated with each Epichloë species (Table 1) (Takach and Young, 2014). At least four unique E. coenophiala genotypes are easily distinguishable among tall fescue sourced originally from Europe and the Mediterranean basin (Ekanayake et al., 2012; Takach and Young, 2014).

Literature surrounding endophyte-infected tall fescue that causes fescue toxicosis often refers to E. coenophiala as the common toxic endophyte. The objective of this study was to compare the endophytes within tall fescue cultivars, varieties and ecotypes from the US using markers to SSRs and alkaloid biosynthesis genes to identify and characterize these endophytes. We have determined endophyte diversity across historical and current tall fescue samples to evaluate the endophyte diversity that may exist across the US.

\section{MATERIALS AND METHODS BIOLOGICAL MATERIALS}

Tall fescue plant material was provided by researchers in Alabama, Arkansas, Georgia, Kentucky, Missouri, Mississippi, New York, Ohio, Oklahoma, Pennsylvania, South Carolina, Tennessee, Texas, and West Virginia (Table 2). Plants were maintained in a space plant nursery under rain-fed conditions or in the greenhouse at the Samuel Roberts Noble Foundation, Ardmore, Oklahoma. Each researcher was requested to provide at least 10 independent 
Table 2 | Sources of tall fescue plants from US collection.

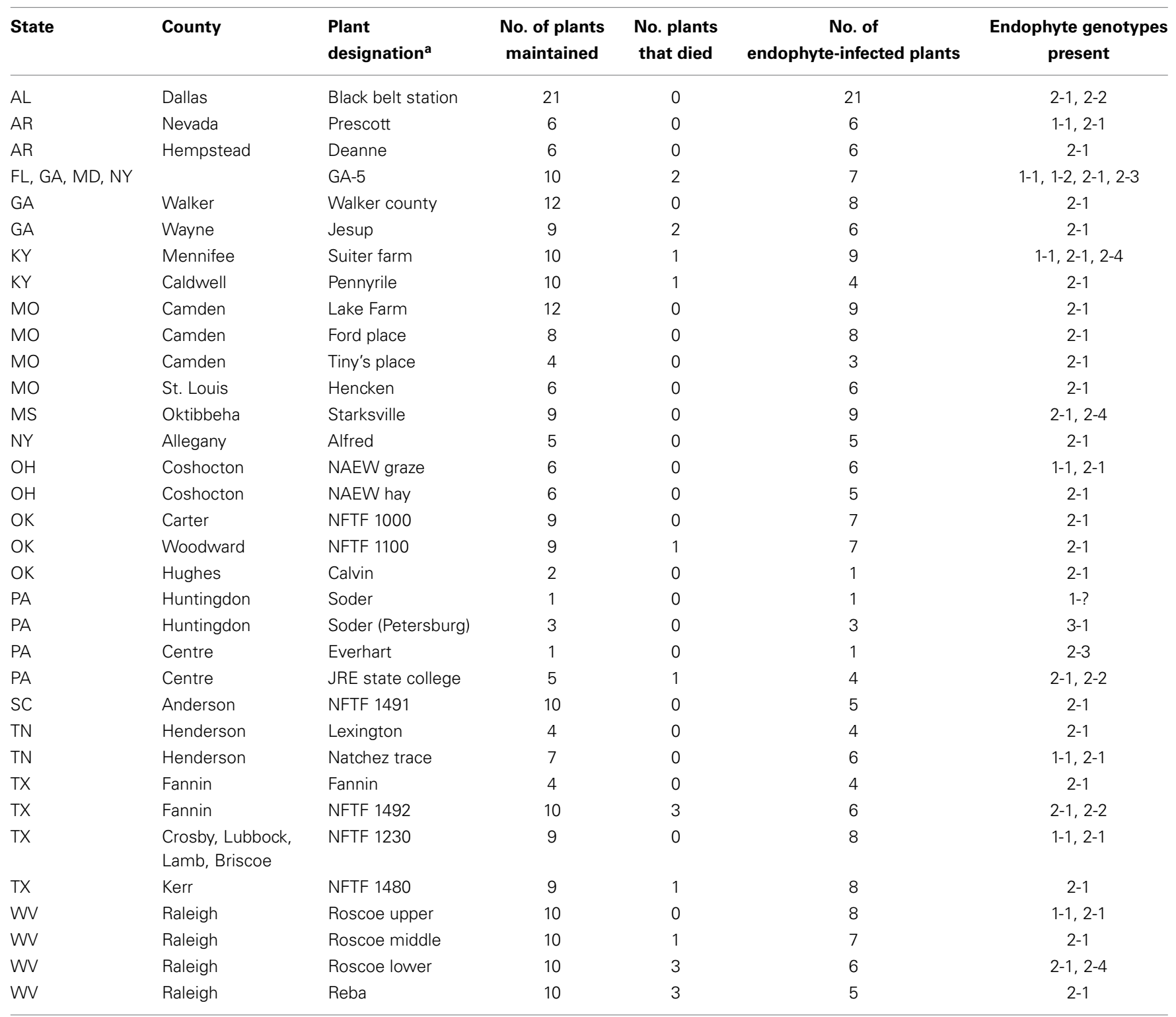

a Plant designation refers to landmark or site location or plant breeding line information (NFTF).

plants from fields known to cause fescue toxicosis or thought to contain the common toxic endophyte. Tall fescue seed stocks (PI lines) were sourced from the National Plant Germplasm System (NPGS). Georgia-5 (GA-5) seed was provided by JH Bouton and other seed stocks were sourced from the Samuel Roberts Noble Foundation tall fescue (NFTF) breeding program and designated NFTF.

\section{DNA ISOLATION AND ENDOPHYTE GENOTYPING}

Total DNA from individual seeds or tillers from stock plants were isolated using QIAGEN MagAttract 96 DNA Plant Core Kit (Qiagen Inc., Valencia, CA). Primers specific for tefA, tef1-exon1d (5'-GGGTAAGGACGAAAAGACTCA-3') and tef1-exon5u-1 (5'CGGCAGCGATAATCAGGATAG-3') (Craven et al., 2001; Moon et al., 2002) were used to detect the presence of endophyte. A minimum set of key alkaloid genes and two mating type genes were chosen to differentiate the E. coenophiala endophytes present in continental tall fescue based on the previous study by Takach and Young (2014). The markers were designed to $m t A C$ and $m t B A$ mating type genes, $d m a W$ and $l p s B$ for representatives of the $E A S$ locus, lolC and lolA for representatives of the LOL locus, idt $G$ and $i d t Q$ for representatives of the IDT locus, and perA second adenylation domain (perA-A2) for PER. Multiplex PCR was performed in a total volume of $25 \mu \mathrm{L}$ containing $3 \mu \mathrm{L}$ DNA, 1.0 U GoTaq ${ }^{\mathrm{TM}}$ DNA Polymerase (Promega Corp., Madison, WI), $1 \times$ Green GoTaq ${ }^{\mathrm{TM}}$ Reaction Buffer containing $1.5 \mathrm{mM} \mathrm{MgCl}_{2}$, $0.2 \mathrm{mM}$ of each dNTP (Promega Corp.), and $1 \mu \mathrm{M}$ of each primer as described previously (Takach et al., 2012; Charlton et al., 2014; Takach and Young, 2014). The cycling parameters were an initial denaturation step for $1 \mathrm{~min}$ at $94 \mathrm{C}, 30$ cycles of denaturation at 
$94 \mathrm{C}$ for $15 \mathrm{~s}$, annealing at $56 \mathrm{C}$ for $30 \mathrm{~s}$, extension at $72 \mathrm{C}$ for $45 \mathrm{~s}$, followed by a final synthesis step at $72 \mathrm{C}$ for $10 \mathrm{~min}$.

PCR of the microsatellite B10 and B11 loci (Moon et al., 1999) were used to differentiate endophytes within an E. coenophiala profile. For SSR analysis, one primer at each locus was end labeled with a fluorescent phosphoramidite dye. Specifically, primers B10.1 was labeled with 2'-chloro-7' phenyl-1,4-dichloro6-carboxy-fluorescein (VIC) and B11.1 was labeled with $2^{\prime}$ chloro-5'-fluoro-7', $8^{\prime}$-benzo-1,4-dichloro-6-carbo xyfluorescein (NED) (Life Technologies, Carlsbad, CA). PCR was performed in a total volume of $10 \mu \mathrm{L}$ containing diluted DNA (approximately $0.5 \mathrm{ng}$ ), $0.75 \mathrm{U}$ Platinum Taq DNA Polymerase (Life Technologies), $1 \times$ PCR Buffer (-Mg), $1.5 \mathrm{mM} \mathrm{MgCl}_{2}, 100 \mathrm{nM}$ of each dNTP (Promega Corp.) and $200 \mathrm{nM}$ of each primer. The cycling parameters were an initial denaturation step for $4 \mathrm{~min}$ at $94 \mathrm{C}, 35$ cycles of denaturation at $94 \mathrm{C}$ for $30 \mathrm{~s}$, annealing at $60 \mathrm{C}$ for $30 \mathrm{~s}$, extension at $72 \mathrm{C}$ for $30 \mathrm{~s}$, followed by a final synthesis step at $72 \mathrm{C}$ for $7 \mathrm{~min}$. PCR products $(1.5 \mu \mathrm{L}$ of a $1: 10$ dilution) were added to $9.9 \mu \mathrm{L}$ of $\mathrm{Hi}$-Di formamide and $0.1 \mu \mathrm{L}$ of GeneScan $^{\mathrm{TM}} 500$ LIZ $^{\mathrm{TM}}$ size standard (Life Technologies). Samples were denatured at $94 \mathrm{C}$ for $5 \mathrm{~min}$ prior to separation on an ABI 3730 DNA Analyzer. Data analysis was performed using Peak Scanner Software v1.0 (Applied Biosystems).

\section{ERGOVALINE ANALYSIS}

Pseudostems were collected from greenhouse grown plants, lyophilized and ground into a fine powder and stored at $-20^{\circ} \mathrm{C}$. Ergovaline concentrations were measured in duplicate using $10 \pm$ $0.10 \mathrm{mg}$ of tissue for each endophyte infected sample. Samples were extracted in $200 \mu \mathrm{L}$ of methanol containing $0.005 \mathrm{mg} / \mathrm{mL}$ dihydroergotamine tartrate salt (Sigma-Aldrich, St. Louis, MO) for $3 \mathrm{~h}$ and then centrifuged at $1800 \times g$ for $5 \mathrm{~min}$. Each sample was analyzed for the presence of ergovaline using an ACQUITY ultra-performance liquid chromatography (UPLC) system (Waters Corporation, Milford, MA) as described previously (Takach et al., 2012). Seed extracts in which the ergovaline content was previously quantified (A. M. Craig, Endophyte Testing Laboratory, Oregon State University) were used as standards for quantification. Concentrations used to generate the standard curve included 0, 50, 97, 500, 1000, and $2000 \mathrm{ppb}$.

The linear standard curve was plotted as ergovaline:ergotamine peak area ratio vs. the actual amount of ergovaline. Standards and samples were analyzed in duplicate and their values averaged.

\section{RESULTS AND DISCUSSION EVALUATION OF HISTORICAL TALL FESCUE ENDOPHYTES FROM THE UNITED STATES}

The cultivar KY31 is well known for causing fescue toxicosis and has been distributed over much of the eastern United States (Figure 1). KY31 was established from an ecotype collection from the Suiter farm in Menifee County, KY (released as a cultivar in 1943) and source material (PI 531431) from this location was deposited into NPGS in 1991. Other cultivars, developed after KY31, have also contributed to the dissemination of endophyteinfected tall fescue (Pedersen and Sleper, 1988). In particular, Alta (cultivar in 1945) was considered a successful cultivar in northeast US and was likely interbred with KY31 (Asay et al., 1979). Seed from other early tall fescue cultivars such as Alta, Kenmont (cultivar in 1963), Kenwell (cultivar in 1965), Kenhy (cultivar in 1977), and Missouri 96 (cultivar in 1977) (Pedersen and Sleper, 1988) were also included in our study (see Table 3 for NPGS deposition

Table 3 | Characterization of endophytes from Kentucky 31 tall fescue seed in US based on microsatellite variation.

\begin{tabular}{|c|c|c|c|c|c|c|}
\hline Seed stock & Year $^{\mathbf{a}}$ & $\begin{array}{l}\text { Seeds } \\
\text { tested }\end{array}$ & $\% E+$ (number) & $\% E-$ (number) & $\begin{array}{c}\% E+\text { Ecoe profile } \\
1^{\text {b }} \text { (number) }\end{array}$ & $\begin{array}{c}\% E+\text { Ecoe profile } \\
2^{\text {b }} \text { (number) }\end{array}$ \\
\hline PI 561431 - KY31 & 1991 & 46 & $91 \%(42)$ & $9 \%(4)$ & $48 \%(22)^{c}$ & $43 \%(20)^{d}$ \\
\hline KY31 commercial seed & 2011 & 48 & $79 \%(38)$ & $21 \%(10)$ & $17 \%(8)^{c}$ & $63 \%(30)^{d}$ \\
\hline KY31 - SW Missouri & 2008 & 46 & $98 \%(45)$ & $2 \%(1)$ & $0 \%(0)$ & $98 \%(45)^{d}$ \\
\hline PI 596701 - Missouri 96 & 1979 & 24 & 0 & $100(24)$ & $0 \%(0)$ & $0 \%(0)$ \\
\hline PI 578714 - Kenmont & 1963 & 24 & 0 & $100(24)$ & $0 \%(0)$ & $0 \%(0)$ \\
\hline PI 574521 - Kenwell & 1965 & 22 & 0 & $100(22)$ & $0 \%(0)$ & $0 \%(0)$ \\
\hline PI 434051 - Kenhy & 1979 & 24 & 0 & $100(24)$ & $0 \%(0)$ & $0 \%(0)$ \\
\hline PI 601020 - Johnstone ${ }^{f}$ & 1983 & 24 & 0 & $100(24)$ & $0 \%(0)$ & $0 \%(0)$ \\
\hline PI 578712 - Alta & 1962 & 48 & 0 & $100(48)$ & $0 \%(0)$ & $0 \%(0)$ \\
\hline Jesup E+ & 2003 & 10 & $100 \%(10)$ & $0 \%(0)$ & $0 \%(0)$ & $100 \%(10)$ \\
\hline NFTF 1000 - PDF $E+^{g}$ & 1998 & 36 & $100 \%(36)$ & $0 \%(0)$ & $8 \%(3)$ & $92 \%(33)$ \\
\hline NFTF 1011 - PDF E+ ${ }^{g}$ & 2007 & 12 & $100 \%(12)$ & $0 \%(0)$ & $33 \%(4)$ & $67 \%(8)$ \\
\hline NFTF 1041 - PDF E+ ${ }^{g}$ & 2010 & 12 & $100 \%(12)$ & $0 \%(0)$ & $0 \%(0)$ & $100 \%(12)$ \\
\hline
\end{tabular}

a The year the seed was purchased, generated or when it entered NPGS.

${ }^{b}$ As determined by markers consistent with E. coenophiala profile 1 and 2 from Table 1.

${ }^{C}$ SSR B10 $=161,170,184 ; B 11=147,191$.

${ }^{d}$ SSR B10 $=152,161,178 ; B 11=171,195$.

e The KY31 commercial seed Tri-Star Seed Co., Inc. located in Spring Hill, KS was purchased from the Tractor Supply Company, Ardmore, Oklahoma, in July 2011.

${ }^{f}$ Johnstone was released as an endophyte free cultivar (Buckner et al., 1983).

${ }^{g}$ NFTF 1011 and NFTF 1041 represent selections from the original NFTF 1000 (also known as PDF E+ Hopkins et al., 2011) from Oklahoma. 
dates). Studies that have included some of these early cultivars have subsequently indicated they were infected with a common toxic endophyte (Bacon et al., 1977; Cornell et al., 1982; Siegel et al., 1984; Pedersen and Sleper, 1988). We also evaluated more recent cultivars and germplasm from the NFTF breeding program that contain common toxic endophyte (Table 3 ).

Seed from each cultivar or line were analyzed for endophyte infection and genetic variation (Table 3). Unfortunately many of the seed samples sourced from NPGS were endophyte-free or had levels less than $5 \%$. Since endophyte viability can be compromised during storage (Siegel et al., 1985; Rolston and Agee, 2007) there was no guarantee these seeds would represent the endophyte status of the original plant material. Only the three KY31 samples, Jesup E+ and NFTF breeding lines were positive for endophyte presence. In addition, two endophyte genotypes, E. coenophiala profile 1 and profile 2 that vary based on presence of IDT genes, could be distinguished in four of these seed samples. However, the percentage of each endophyte strain varied in each seed lot. Four of the tested seed lines, KY31 (from Missouri), Jesup E+ and NFTF 1041 may represent an E. coenophiala profile 2 monoculture, or contain a low incidence of E. coenophiala profile 1 as the number of seeds tested for some lines were low (Table 3).

Lines that were selected from NFTF 1000-PDF (NFTF 1011 selected from PDF for vigorous growth, high forage yield and digestibility, and NFTF 1041 selected from PDF for high digestibility by marker assisted selection) showed different ratios of each E. coenophiala profile (Table 3). This may show the influence an endophyte strain, which is maintained in the maternal line, can have on selectable traits such as persistence and vigor if the endophyte provides a host advantage. As such, it would be interesting to evaluate the host genetic shifts under selection, with and without endophytes, while also following selection of different endophyte strains.

\section{ENDOPHYTE ANALYSIS FROM DEVELOPMENT OF THE CULTIVAR GEORGIA-5}

Analysis of endophyte variation within a population provides an opportunity to evaluate material incorporated through a tall fescue breeding pipeline and eventually released for commercial production (Figure 2). The GA-5 cultivar was developed as a synthetic endophyte-infected cultivar with superior forage yield and persistence in the Southern Coastal Plains that had potential to replace KY31 (Bouton et al., 1993b). The cultivar was established from five clones and was shown to be $75 \%$ endophyte infected (Bouton et al., 1993b). We evaluated seed from the original five clones (each clone having originated from a different location) using markers to SSRs and alkaloid biosynthesis genes to determine the initial infection rates of each clone and identify which E. coenophiala profiles were present. The endophyte status of the originating lines varied from 32 to $100 \%$ infection, and the endophyte profiles were consistent within the seed sample from each clone. Three independent endophyte genotypes (based on SSRs) were identified within the clones (Figure 2). Seed from synthetic 1 established in 1980 was also tested for endophyte infection and identification, and all three endophyte genotypes were represented within this sample with an overall endophyte infection level of 79\% (Figure 2). In 1993, GA-5 was registered as a cultivar
(Bouton et al., 1993b) and subsequently released commercially in 1996. When we evaluated a seed stock from the commercial line the overall infection level was $69 \%$ and two of the three expected endophyte SSR profiles were identified within the sample. However, an additional endophyte genotype $(\mathrm{B} 10=152,161$, 178 and $\mathrm{B} 11=171,195)$ was present in $5 \%$ of the seed sample (Figure 2) that has likely arisen from contamination later in production. The level of endophyte free seed increased from Syn 1 $(21 \%)$ to Syn $6(31 \%)$ and may indicate that production favored this part of the population. Unfortunately we were unable to detect the endophyte genotype profile 2 with $\mathrm{B} 10=161,173,178$ and $\mathrm{B} 11=171,195$, which may be due to the number of seeds that were tested.

\section{ENDOPHYTE DIVERSITY FROM US TALL FESCUE COLLECTIONS}

To further examine tall fescue endophyte diversity within the US, collections of tall fescue plants from 14 eastern states were evaluated for endophyte presence. In total, 246 tall fescue plants were screened using markers for SSRs B10 and B11, and the minimum set of alkaloid biosynthesis genes to distinguish the different E. coenophiala genetic profiles. Of the 246 plants initially screened, $204(83 \%)$ were endophyte-infected. All of the endophyte-infected samples could be amplified with primer sets to $m t A C$, perA, and the $L O L$ and $E A S$ markers, and samples only varied with the presence of IDT markers. Three E. coenophiala genetic profiles were identified (E. coenophiala profiles 1, 2, and 3; Table 4).

Further analysis using the B10 and B11 SSR markers showed additional variation within the genetic profiles. There were two unique SSR profiles for genotype 1, four SSR profiles for genotype 2 and one SSR profile for genotype 3. E. coenophiala profile 1 is consistent with the same pattern of the KY31 endophyte E. coenophiala strain e19 (Schardl et al., 1991; Takach and Young, 2014), while E. coenophiala profile 2 is more highly represented in the samples.

The two most common SSR marker patterns were also identified in the KY31 seed (Table 3). Interestingly, of the nine plants that were collected from the original Suiter farm (Table 2), one plant showed a third unique SSR profile in common with endophytes found in West Virginia and Mississippi. Only one set of plants from Pennsylvania produced E. coenophiala genetic profile 3 , but unfortunately knowledge about the tall fescue planted at this site was unavailable. This Pennsylvania endophyte-infected tall fescue is the only set of plants that were likely to produce indole-diterpenes.

Plants with unique E. coenophiala profiles were selected from the nursery and maintained in the greenhouse. Ergovaline was analyzed from pseudostems of 25 plants representing the seven unique E. coenophiala profiles. Each of the plant-endophyte associations produced ergovaline (Table 5), indicating that the endophyte in these lines would all be considered a common toxic endophyte. The ergovaline levels generated under greenhouse conditions were also extremely high, well above the threshold of 400-750 ppb required for toxicity in livestock (Hovermale and Craig, 2001). Although the levels tested from these plants are high, it may simply reflect they were well maintained plants subjected to regular fertilization, which is known to result 


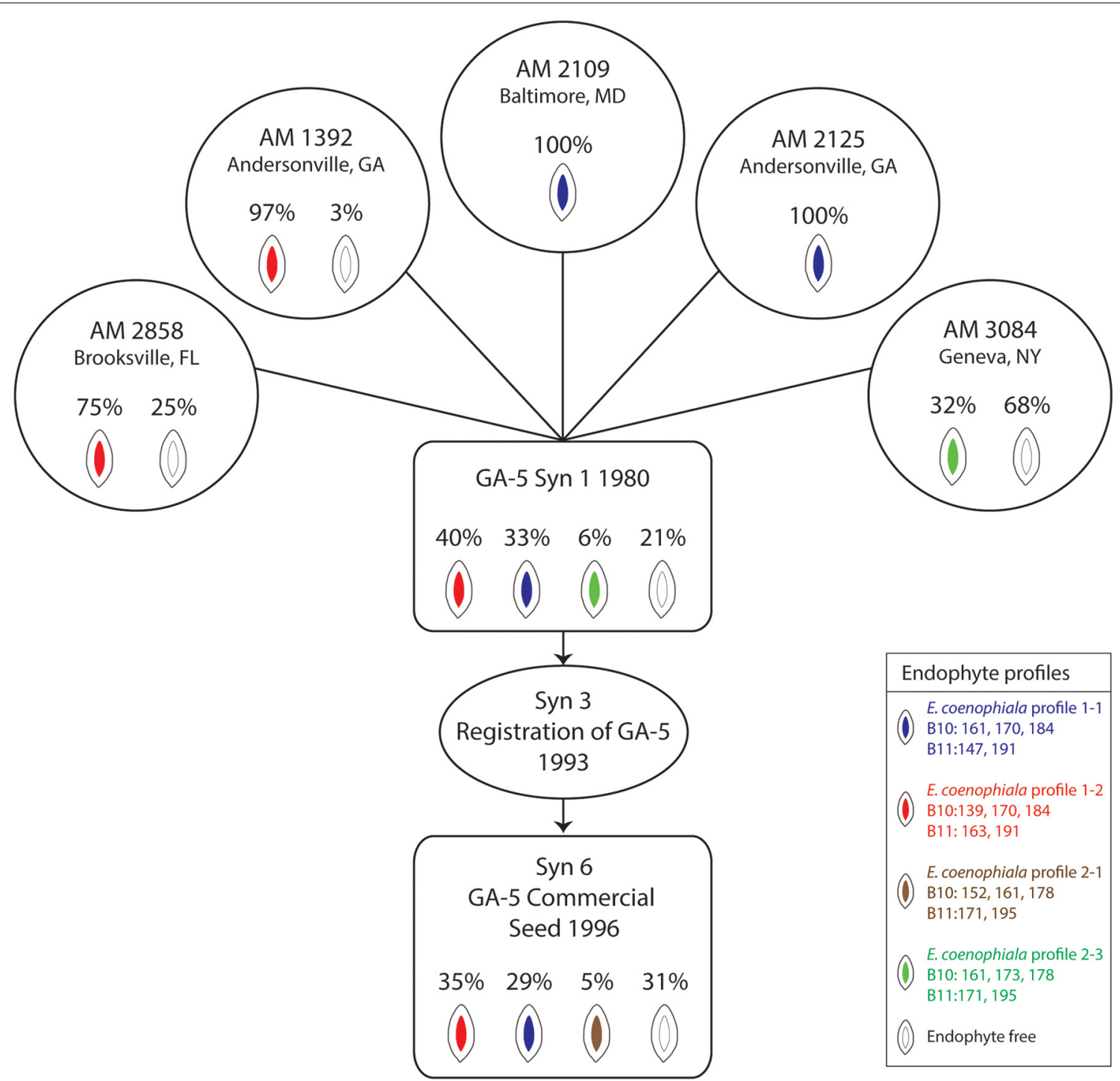

FIGURE 2 | Epichloë coenophiala profiles and infection frequencies of seed used in the development of the "Georgia 5" tall fescue cultivar. The five clones consisted of AM 1392, AM 2109,
AM 2125, AM 2858, and AM 3084. The synthetic 3 generation represents the breeders seed increase from the five clones (Bouton et al., 1993b). in higher levels of ergovaline production (Rottinghaus et al., 1991).

This study provides a snapshot of common toxic endophyteinfected tall fescue across the eastern US. The endophyte genotypes we identified were consistent with samples from Europe where tall fescue was originally sourced (Takach and Young, 2014). Endophyte genotype diversity was present at the origin of KY31 but it appears E. coenophiala genotype 2 is the dominant endophyte genotype across the US. This endophyte was also prevalent in other breeding populations such as Jesup E+ and NFTF 1000. Given the sample numbers we have selected from each location, it is still possible that other endophyte genotypes are present at low frequencies. Although KY31 is believed to be the predominant source of tall fescue in the US, other sources were developed and planted at various times and locations, and it is possible that during this process one endophyte genotype provided a selectable advantage. Indeed, if we look at NFTF 1011, a selection from the NFTF 1000 line (Table 3), we see a shift in endophyte genotype that may be due to specific selection pressures.

\section{NEW CULTIVARS WITH SELECTED ENDOPHYTES}

To overcome fescue toxicosis, researchers initially removed the endophyte from toxic tall fescue. Unfortunately, studies that evaluated the endophyte role on tall fescue performance found endophyte-infected lines had better persistence and greater yield than endophyte-free lines (Pedersen et al., 1990; Bouton et al., 1993a, 2002; West et al., 1993; Gunter and Beck, 2004). As expected, when production of ergot alkaloids was low or not present, livestock also had better overall performance and 
Table 4 | Characterization of endophytes from tall fescue plants in US based on alkaloid profiles and microsatellite variation.

\begin{tabular}{|c|c|c|c|c|c|c|c|c|c|c|c|}
\hline \multirow{2}{*}{$\begin{array}{l}\text { Endophyte } \\
\text { genotype }\end{array}$} & \multirow{2}{*}{$\begin{array}{l}\text { B10 allele } \\
\text { sizes (bp) }\end{array}$} & \multirow{2}{*}{$\begin{array}{l}\text { B11 allele } \\
\text { sizes (bp) }\end{array}$} & \multirow{2}{*}{$\frac{\text { PER }^{\mathrm{a}}}{\text { perA-A2 }}$} & \multicolumn{2}{|c|}{$E A S^{\mathrm{a}}$} & \multicolumn{2}{|c|}{$L O L^{\mathrm{a}}$} & \multicolumn{2}{|c|}{$I D T^{\mathrm{a}}$} & \multirow{2}{*}{$\begin{array}{l}\text { No. of } \\
\text { plants }\end{array}$} & \multirow[t]{2}{*}{ States } \\
\hline & & & & dmaW & IpsB & IoIC & IolA & $i d t G$ & ItmQ & & \\
\hline E. coenophiala profile 1-1 & $161,170,184$ & 147,191 & + & + & + & + & + & & & 11 & $\mathrm{AR}, \mathrm{KY}, \mathrm{OH}, \mathrm{TN}, \mathrm{TX}, \mathrm{WV}$ \\
\hline E. coenophiala profile 1-2 & $139,170,184$ & 163,191 & + & + & + & + & + & & & 2 & GA \\
\hline E. coenophiala profile 2-1 & $152,161,178$ & 171,195 & + & + & + & + & + & & + & 172 & $\begin{array}{l}\mathrm{AL}, \mathrm{AR}, \mathrm{GA}, \mathrm{KY}, \mathrm{MO}, \mathrm{MS}, \\
\mathrm{NY}, \mathrm{OH}, \mathrm{OK}, \mathrm{PA}, \mathrm{SC}, \mathrm{TN}, \\
\mathrm{TX}, \mathrm{WV}\end{array}$ \\
\hline E. coenophiala profile 2-2 & $152,161,178$ & 183,195 & + & + & + & + & + & & + & 3 & $\mathrm{AL}, \mathrm{TX}$ \\
\hline E. coenophiala profile 2-3 & $161,173,178$ & 171,195 & + & + & + & + & + & & + & 3 & $\mathrm{GA}(N Y)^{\mathrm{b}}, \mathrm{PA}$ \\
\hline E. coenophiala profile 2-4 & $161,173,178$ & 171,210 & + & + & + & + & + & & + & 4 & $\mathrm{KY}, \mathrm{MS}, \mathrm{WV}$ \\
\hline E. coenophiala profile 3-1 & $161,170,178$ & 155,163 & + & + & + & + & + & + & + & 3 & PA \\
\hline
\end{tabular}

a The + indicates that a PCR fragment was detected with primers designed to the gene.

${ }^{b}$ /dentified out of GA-5 and represents the clone from NY (see Figure 2).

Table 5 | Ergovaline concentrations of tall fescue infected with different Epichloë coenophiala genotypes.

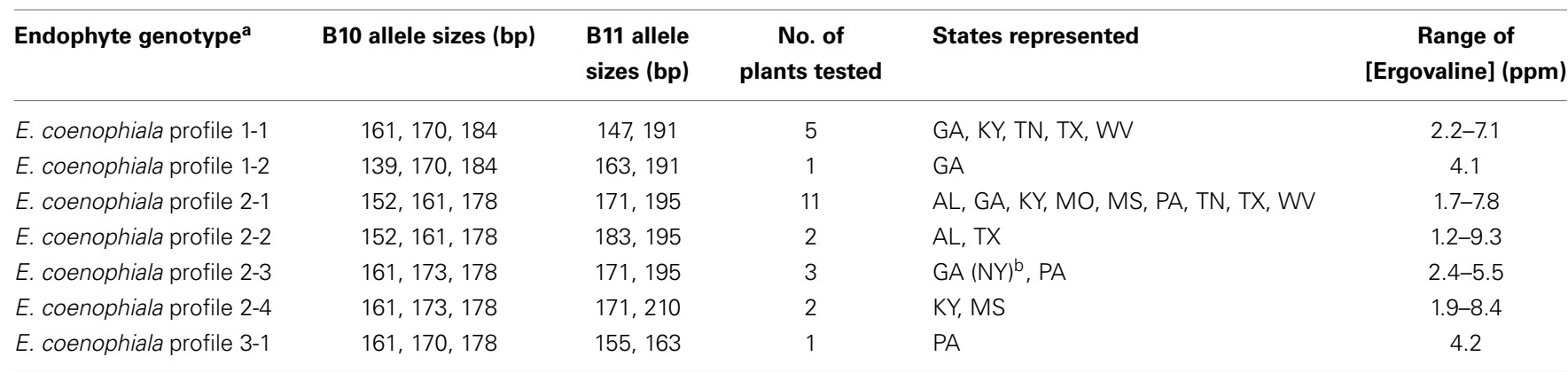

a Based on designations from Takach and Young (2014).

b/dentified from the GA-5 line and represents the clone from NY (see Figure 2).

increased average daily gains (Stuedemann and Hoveland, 1988; Gunter and Beck, 2004). An ideal solution to capture both endophyte associated plant persistence and reduced livestock toxicity was to identify an endophyte strain that retained traits for plant persistence, but did not produce the alkaloids toxic to livestock. Analysis of tall fescue across its natural distribution of Europe and the Mediterranean basin has shown diversity of both the endophyte (Christensen et al., 1993; Ekanayake et al., 2012; Takach and Young, 2014) and its plant host (Hand et al., 2012); subsequently this diversity has been exploited to establish selected endophyte-infected tall fescue with low mammalian toxicity (reviewed in Bouton, 2009; Johnson et al., 2013; Young et al., 2013). Typically these endophytes lack many or all of the genes at the EAS locus required for ergot alkaloid biosynthesis (e.g., E. coenophiala profile 4, Table 1) (Takach and Young, 2014), although some endophytes have been selected for lower ergot alkaloid production.

Initial success with selected endophytes was observed when the endophyte strain AR542 (known commercially as MaxQ and MaxP in the US and Australia, respectively) was inoculated into Jesup and GA-5 (Bouton et al., 2002). Agronomic evaluations indicated selected endophyte-tall fescue associations provided the benefits of endophyte infection (stand persistence) with animal performance similar to endophyte-free tall fescue (Bouton et al.,
2002; Parish et al., 2003; Gunter and Beck, 2004). Jesup MaxQ (Pennington Seed, Inc.) was the first commercial tall fescue cultivar to be released and used by farmers containing a selected endophyte. Additional endophyte-infected tall fescue lines have since been established and evaluated for both plant and animal performance (Roberts and Andrae, 2004; Hopkins et al., 2010; Parish et al., 2013; Beck et al., 2014). One of the most recently released cultivars, Texoma MaxQ II, is the result of breeding for plant persistence with an ecotypic selection that was subsequently inoculated with the endophyte strain AR584 (MaxQ II) that does not cause livestock toxicity (Hopkins et al., 2010, 2011). Current commercially available cultivars of selected endophytetall fescue associations include: Jesup MaxQ (Pennington Seed, Inc.), Texoma MaxQ (Pennington Seed Inc.), BarOptima Plus E34 (Barenbrug), Duramax Gold (DLF International Seeds), and Estancia with ArkShield (MountainView Seeds).

\section{CONCLUSION}

Endophytes have clearly affected the success of tall fescue within the US, from the prevalence of the common toxic endophyte through to advancing cultivars with selected endophytes. Many farmers have learned to manage the effects of fescue toxicosis through pasture management techniques, but now there are also options for eliminating toxicity by pasture replacement. The 
availability of elite tall fescue lines infected with selected endophytes allows farmers to provide nutritious, non-toxic feed for their livestock without fear of toxic repercussions. Climate change will likely increase the dependency of tall fescue monocultures to rely upon endophytes to provide drought tolerance and protection from insect pests. As more selected endophyte-infected cultivars enter the marketplace to replace tall fescue pastures containing common toxic endophytes, we will be able to examine the constancy of these symbiotic associations over time. Utilization of molecular markers will provide effective methods to identify endophyte strains within tall fescue cultivars, varieties and ecotypes, and help distinguish endophyte friend from foe.

\section{ACKNOWLEDGMENTS}

We would like to acknowledge Joe Bouton for providing seed and Simon Abel, Sherrita Bright, and Kenny Word for technical support. We thank Lark Trammell (Forage Analysis Core Facility), the Genomic Core Facility and the Greenhouse Core Facility at The Samuel Roberts Noble Foundation for technical support. The authors thank the following people who provided plants from the listed states: Don Ball (AL), Rob Kallenbach (MO), David Belesky (WV), Gerald Atkinson (KY), Gary Lacefield (KY), Norman Edwards (GA), James Hopkins (MO), Howard Skinner (PA and NY), David Barker (OH), James Rogers (OK and SC), Joseph Bouton (GA), Jimmy Ray Parish (MS), Steve Green (AR), Paul Beck (AR), and Jack Chapman (OK). The Samuel Roberts Noble Foundation provided financial support for this research.

\section{REFERENCES}

Arachevaleta, M., Bacon, C. W., Hoveland, C. S., and Radcliffe, D. E. (1989). Effect of the tall fescue endophyte on plant response to environmental stress. Agron. J. 81, 83-90. doi: 10.2134/agronj1989.00021962008100010015x

Asay, K., Frakes, R. V., and Buckner, R. C. (1979). "Breeding and cultivars," in Tall Fescue, eds R. Buckner and L. Bush (Madison, WI: American Society of Agronomy, Crop Science Society of America, Soil Science Society of America), 111-139.

Bacon, C., Porter, J., Robbins, J., and Luttrell, E. (1977). Epichloë typhina from toxic tall fescue grasses. Appl. Environ. Microbiol. 34, 576-581.

Bacon, C. W. (1988). Procedure for isolating the endophyte from tall fescue and screening isolates for ergot alkaloids. Appl. Environ. Microbiol. 54, 2615-2618.

Bacon, C. W., Lyons, P. C., Porter, J. K., and Robbins, J. D. (1986). Ergot toxicity from endophyte-infected grasses: a review. Agron. J. 78, 106-116. doi: 10.2134/agronj1986.00021962007800010023x

Ball, D. M., Pederson, J., and Lacefield, G. D. (1993). The tall-fescue endophyte. Am. Sci. 81, 370-379.

Beck, P., Stewart, C., Gray, H., Gadberry, M., Gunter, S., Young, C., et al. (2014). Using tall fescue in a complementary grazing program for Spring calving beef cows in Southern Arkansas. Prof. Anim. Sci. 30, 423-431.

Bouton, J. (2009). "Deployment of novel endophytes in the tall fescue commercial seed trade," in Tall Fescue for the Twenty-First Century, Agronomy Monograph 53, eds H. Fribourg, D. Hannaway, and C. West (Madison, WI: American Society of Agronomy, Crop Science Society of America, Soil Science Society of America), 367-375.

Bouton, J., Gates, R., Belesky, D., and Owsley, M. (1993a). Yield and persistence of tall fescue in the southeastern coastal plain after removal of its endophyte. Agron. J. 85, 52-55. doi: 10.2134/agronj1993.000219620085000 $10011 \mathrm{x}$

Bouton, J., Gates, R., Hill, G., Owsley, M., and Wood, D. (1993b). Registration of 'Georgia 5' tall fescue. Crop Sci. 33, 1405. doi: 10.2135/cropsci1993.0011183X003300060059x

Bouton, J. H., Latch, G. C., Hill, N. S., Hoveland, C. S., McCann, M. A., Watson, R. H., et al. (2002). Reinfection of tall fescue cultivars with non-ergot alkaloidproducing endophytes. Agron. J. 94, 567-574. doi: 10.2134/agronj2002.0567
Buckner, R., Boling, J., Burrus, P., Bush, L., and Hemken, R. (1983). Registration of Johnstone tall fescue (Reg. No. 23). Crop Sci. 23, 399-400. doi: 10.2135/cropsci1983.0011183X002300020057x

Bush, L., Boling, J., and Yates, S. (1979). "Animal disorders," in Tall Fescue, eds R. C. Buckner and L. P. Bush (Madison, WI: American Society of Agronomy, Crop Science Society of America, Soil Science Society of America), 247-292.

Bush, L. P., Wilkinson, H. H., and Schardl, C. L. (1997). Bioprotective alkaloids of grass-fungal endophyte symbioses. Plant Physiol. 114, 1-7.

Caldwell, J. D., Coffey, K. P., Jennings, J. A., Philipp, D., Young, A. N., Tucker, J. D., Hubbell, D. S. 3rd., et al. (2013). Performance by spring and fall-calving cows grazing with full, limited, or no access to toxic Neotyphodium coenophialuminfected tall fescue. J. Anim. Sci. 91, 465-476. doi: 10.2527/jas.2011-4603

Charlton, N. D., Craven, K. D., Afkhami, M. E., Hall, B. H., Ghimire, S. R., and Young, C. A. (2014). Interspecific hybridization and bioactive alkaloid variation increases diversity in endophytic Epichloë species of Bromus laevipes. FEMS Microbiol. Ecol. 90, 276-289. doi: 10.1111/1574-6941.12393

Charlton, N. D., Craven, K. D., Mittal, S., Hopkins, A. A., and Young, C. A. (2012). Epichloë canadensis, a new interspecific epichloid hybrid symbiotic with Canada wildrye (Elymus canadensis). Mycologia 104, 1187-1199. doi: 10.3852/11-403

Christensen, M., and Latch, G. (1991). Variation among isolates of Acremonium endophytes (A. coenophialum and possibly A. typhinum) from tall fescue (Festuca arundinacea). Mycol. Res. 95, 1123-1126. doi: 10.1016/S09537562(09)80558-3

Christensen, M., Leuchtmann, A., Rowan, D., and Tapper, B. (1993). Taxonomy of Acremonium endophytes of tall fescue (Festuca arundinacea), meadow fescue (F. pratensis) and perennial ryegrass (Lolium perenne). Mycol. Res. 97, 1083-1092. doi: 10.1016/S0953-7562(09)80509-1

Clay, K., Hardy, T. N., and Hammond, A. M. (1985). Fungal endophytes of grasses and their effects on an insect herbivore. Oecologia 66, 1-5. doi: 10.1007/BF00378545

Cornell, C., Garner, G., Yates, S., and Bell, S. (1982). Comparative fescue foot potential of fescue varieties. J. Anim. Sci. 55, 180-184.

Craven, K. D., Hsiau, P. T. W., Leuchtmann, A., Hollin, W., and Schardl, C. L. (2001). Multigene phylogeny of Epichloë species, fungal symbionts of grasses. Ann. Mo. Bot. Gard. 88, 14-34. doi: 10.2307/2666129

Cunningham, I. (1948). Tall fescue grass is poison for cattle. N.Z. J. Agric. 77, 519.

Cunningham, I. (1949). A note on the cause of tall fescue lameness in cattle. Aust. Vet. J. 25, 27-28. doi: 10.1111/j.1751-0813.1949.tb04752.x

Ekanayake, P. N., Hand, M. L., Spangenberg, G. C., Forster, J. W., and Guthridge, K. M. (2012). Genetic diversity and host specificity of fungal endophyte taxa in fescue pasture grasses. Crop Sci. 52, 2243-2252. doi: 10.2135/cropsci2011. 12.0664

Fergus, E., and Buckner, R. C. (1972). Registration of Kentucky 31 Tall Fescue (Reg. No. 7). Crop Sci. 12, 714. doi: 10.2135/cropsci1972.0011183X001200050061x

Fleetwood, D. J., Scott, B., Lane, G. A., Tanaka, A., and Johnson, R. D. (2007). A complex ergovaline gene cluster in Epichloë endophytes of grasses. Appl. Environ. Microbiol. 73, 2571-2579. doi: 10.1128/AEM.00257-07

Fletcher, L. R., and Harvey, I. C. (1981). An association of a Lolium endophyte with ryegrass staggers. N.Z. Vet. J. 29, 185-186. doi: 10.1080/00480169.1981.34839

Glenn, A. E., Bacon, C. W., Price, R., and Hanlin, R. T. (1996). Molecular phylogeny of Acremonium and its taxonomic implications. Mycologia 88, 369-383. doi: $10.2307 / 3760878$

Groppe, K., Sanders, I., Wiemken, A., and Boller, T. (1995). A microsatellite marker for studying the ecology and diversity of fungal endophytes (Epichloë spp.) in grasses. Appl. Environ. Microbiol. 61, 3943-3949.

Gunter, S., and Beck, P. (2004). Novel endophyte-infected tall fescue for growing beef cattle. J. Anim. Sci. 82, E75-E82.

Hand, M. L., Cogan, N. O., and Forster, J. W. (2012). Molecular characterisation and interpretation of genetic diversity within globally distributed germplasm collections of tall fescue (Festuca arundinacea Schreb.) and meadow fescue (F. pratensis Huds.). Theor. Appl. Genet. 124, 1127-1137. doi: 10.1007/s00122011-1774-6

Hemken, R., Jackson, J. Jr., and Boling, J. (1984). Toxic factors in tall fescue. J. Anim. Sci. 58, 1011-1016.

Hopkins, A., Young, C., Butler, T., and Bouton, J. (2011). Registration of 'Texoma'MaxQ II tall fescue. J. Plant Regist. 5, 14-18. doi: $10.3198 /$ jpr2010.02.0082crc

Hopkins, A., Young, C., Panaccione, D., Simpson, W., Mittal, S., and Bouton, J. (2010). Agronomic performance and lamb health among several tall fescue 
novel endophyte combinations in the south-central USA. Crop Sci. 50, 1552-1561. doi: 10.2135/cropsci2009.08.0473

Hoveland, C., Schmidt, S., King, C., Odom, J., Clark, E., McGuire, J., et al. (1983). Steer performance and association of Acremonium coenophialum fungal endophyte on tall fescue pasture. Agron. J. 75, 821-824. doi: 10.2134/agronj1983.00021962007500050021x

Hoveland, C. S. (2009). "Origin and history," in Tall Fescue for the 21st Century, eds H. Fribourg, D. Hannaway, and C. West (Madison, WI: Amer Society of Agronomy), 3-10.

Hovermale, J. T., and Craig, A. M. (2001). Correlation of ergovaline and lolitrem B levels in endophyte-infected perennial ryegrass (Lolium perenne). J. Vet. Diagn. Invest. 13, 323-327. doi: 10.1177/104063870101300407

Jacobson, D., Miller, W., Seath, D., Yates, S., Tookey, H., and Wolff, I. (1963). Nature of fescue toxicity and progress toward identification of the toxic entity. J. Dairy Sci. 46, 416-422. doi: 10.3168/jds.S0022-0302(63)89066-9

Johnson, L. J., de Bonth, A. C., Briggs, L. R., Caradus, J. R., Finch, S. C., Fleetwood, D. J., et al. (2013). The exploitation of epichloae endophytes for agricultural benefit. Fungal Divers. 60, 171-188. doi: 10.1007/s13225-013-0239-4

Johnson, M. C., Dahlman, D. L., Siegel, M. R., Bush, L. P., Latch, G. C., Potter, D. A., et al. (1985). Insect feeding deterrents in endophyte-infected tall fescue. Appl. Environ. Microbiol. 49, 568-571.

Leuchtmann, A., Bacon, C. W., Schardl, C. L., White, J. F., and Tadych, M. (2014). Nomenclatural realignment of Neotyphodium species with genus Epichloë. Mycologia 106, 202-215. doi: 10.3852/106.2.202

Leuchtmann, A., and Clay, K. (1990). Isozyme variation in the Acremonium/Epichloë fungal endophyte complex. Phytopathology 80, 1133-1139. doi: 10.1094/Phyto-80-1133

Leuchtmann, A., Schmidt, D., and Bush, L. (2000). Different levels of protective alkaloids in grasses with stroma-forming and seed-transmitted Epichloë/Neotyphodium endophytes. J. Chem. Ecol. 26, 1025-1036. doi: 10.1023/A:1005489032025

Lyons, P. C., Plattner, R. D., and Bacon, C. W. (1986). Occurrence of peptide and clavine ergot alkaloids in tall fescue grass. Science 232, 487-489. doi: $10.1126 /$ science. 3008328

Malinowski, D. P., and Belesky, D. P. (2000). Adaptations of endophyte-infected cool-season grasses to environmental stresses: mechanisms of drought and mineral stress tolerance. Crop Sci. 40, 923-940. doi: 10.2135/cropsci2000.404923x

Moon, C. D., Craven, K. D., Leuchtmann, A., Clement, S. L., and Schardl, C. L. (2004). Prevalence of interspecific hybrids amongst asexual fungal endophytes of grasses. Mol. Ecol. 13, 1455-1467. doi: 10.1111/j.1365-294X.2004.02138.x

Moon, C. D., Miles, C. O., Jarlfors, U., and Schardl, C. L. (2002). The evolutionary origins of three new Neotyphodium endophyte species from grasses indigenous to the Southern Hemisphere. Mycologia 94, 694-711. doi: 10.2307/ 3761720

Moon, C. D., Tapper, B. A., and Scott, B. (1999). Identification of Epichloë endophytes in planta by a microsatellite-based PCR fingerprinting assay with automated analysis. Appl. Environ. Microbiol. 65, 1268-1279.

Morgan-Jones, G., and Gams, W. (1982). Notes on Hyphomycetes. XLI. An endophyte of Festuca arundinacea and the anamorph of Epichloe typhina, new taxa in one of two new sections of Acremonium. Mycotaxon 15, 311-318.

Pan, J., Bhardwaj, M., Faulkner, J. R., Nagabhyru, P., Charlton, N. D., Higashi, R. M., et al. (2014). Ether bridge formation in loline alkaloid biosynthesis. Phytochemistry 98, 60-68. doi: 10.1016/j.phytochem.2013.11.015

Panaccione, D. G., Johnson, R. D., Wang, J., Young, C. A., Damrongkool, P., Scott, B., et al. (2001). Elimination of ergovaline from a grass-Neotyphodium endophyte symbiosis by genetic modification of the endophyte. Proc. Natl. Acad. Sci. U.S.A. 98, 12820-12825. doi: 10.1073/pnas.221198698

Parish, J. A., McCann, M. A., Watson, R. H., Paiva, N. N., Hoveland, C. S., Parks, A. H., et al. (2003). Use of nonergot alkaloid-producing endophytes for alleviating tall fescue toxicosis in stocker cattle. J. Anim. Sci. 81, 2856-2868.

Parish, J. A., Parish, J. R., Best, T. F., Boland, H. T., and Young, C. A. (2013). Effects of selected endophyte and tall fescue cultivar combinations on steer grazing performance, indicators of fescue toxicosis, feedlot performance, and carcass traits. J. Anim. Sci. 91, 342-355. doi: 10.2527/jas.2011-4725

Pedersen, J., Lacefield, G., and Ball, D. (1990). A review of the agronomic characteristics of endophyte-free and endophyte-infected tall fescue. Appl. Agric. Res. 5, 188-194.

Pedersen, J., and Sleper, D. (1988). Considerations in breeding endophyte-free tall fescue forage cultivars. J. Prod. Agric. 1, 127-132. doi: 10.2134/jpa1988.0127
Porter, J. K., Bacon, C. W., and Robbins, J. D. (1979). Ergosine, ergosinine, and chanoclavine I from Epichloë typhina. J. Agric. Food Chem. 27, 595-598. doi: 10.1021/jf60223a045

Roberts, C., and Andrae, J. (2004). Tall fescue toxicosis and management. Crop Manage. 3. doi: 10.1094/CM-2004-0427-01-MG

Rolston, M., and Agee, C. (2007). "Delivering quality seed to specificationthe USA and NZ novel endophyte experience," in Proceedings of the 6th International Symposium on Fungal Endophytes of Grasses. Christchurch, New Zealand. Grassland Research and Practice Series, eds A. Popay and E. Thom (Dunedin, NZ: NZ Grassl. Assoc. Inc.), 229-231.

Rottinghaus, G. E., Garner, G. B., Cornell, C. N., and Ellis, J. L. (1991). HPLC method for quantitating ergovaline in endophyte-infested tall fescue: seasonal variation of ergovaline levels in stems with leaf sheaths, leaf blades, and seed heads. J. Agric. Food Chem. 39, 112-115. doi: 10.1021/jf000 01a022

Rowan, D., and Latch, G. (1994). "Utilization of endophyte-infected perennial ryegrasses for increased insect resistance," in Biotechnology of Endophytic Fungi of Grasses, eds C. W. Bacon and J. F. J. White (Boca Raton, FL: CRC Press), 169-183.

Saikia, S., Takemoto, D., Tapper, B. A., Lane, G. A., Fraser, K., and Scott, B. (2012) Functional analysis of an indole-diterpene gene cluster for lolitrem $B$ biosynthesis in the grass endosymbiont Epichloë festucae. FEBS Lett. 586, 2563-2569. doi: 10.1016/j.febslet.2012.06.035

Schardl, C. L. (2001). Epichloë festucae and related mutualistic symbionts of grasses. Fungal Genet. Biol. 33, 69-82. doi: 10.1006/fgbi.2001.1275

Schardl, C. L., Liu, J., White, J. F. Jr., Finkel, R. A., An, Z., and Siegel, M. R. (1991). Molecular phylogenetic relationships of nonpathogenic grass mycosymbionts and clavicipitaceous plant pathogens. Plant Syst. Evol. 178, 27-41. doi: 10.1007/BF00937980

Schardl, C. L., Young, C. A., Hesse, U., Amyotte, S. G., Andreeva, K., Calie, P. J., et al. (2013a). Plant-symbiotic fungi as chemical engineers: multi-genome analysis of the Clavicipitaceae reveals dynamics of alkaloid loci. PLoS Genet. 9:e1003323. doi: 10.1371/journal.pgen.1003323

Schardl, C. L., Young, C. A., Pan, J., Florea, S., Takach, J. E., Panaccione, D. G., et al. (2013b). Currencies of mutualisms: sources of alkaloid genes in vertically transmitted Epichloae. Toxins 5, 1064-1088. doi: 10.3390/toxins5061064

Siegel, M., Latch, G., Bush, L., Fannin, F., Rowan, D., Tapper, B., et al. (1990). Fungal endophyte-infected grasses: alkaloid accumulation and aphid response. J. Chem. Ecol. 16, 3301-3315. doi: 10.1007/BF00982100

Siegel, M. R., Johnson, M. C., Varney, D., Nesmith, W., Buckner, R., Bush, L. P., et al. (1984). A fungal endophyte in tall fescue: incidence and dissemination. Phytopathology 74, 932-937. doi: 10.1094/Phyto-74-932

Siegel, M. R., Latch, G. C. M., and Johnson, M. C. (1985). Acremonium fungal endophytes of tall fescue and perennial ryegrass: significance and control. Plant Dis. $69,179-181$.

Spiering, M. J., Faulkner, J. R., Zhang, D. X., Machado, C., Grossman, R. B., and Schardl, C. L. (2008). Role of the LolP cytochrome P450 monooxygenase in loline alkaloid biosynthesis. Fungal Genet. Biol. 45, 1307-1314. doi: 10.1016/j.fgb.2008.07.001

Spiering, M. J., Moon, C. D., Wilkinson, H. H., and Schardl, C. L. (2005). Gene clusters for insecticidal loline alkaloids in the grass-endophytic fungus Neotyphodium uncinatum. Genetics 169, 1403-1414. doi: 10.1534/genetics.104.035972

Stuedemann, J. A., and Hoveland, C. S. (1988). Fescue endophyte: history and impact on animal agriculture. J. Prod. Agric. 1, 39-44. doi: 10.2134/jpa1988.0039

Takach, J. E., Mittal, S., Swoboda, G. A., Bright, S. K., Trammell, M. A., Hopkins, A. A., et al. (2012). Genotypic and chemotypic diversity of Neotyphodium endophytes in tall fescue from Greece. Appl. Environ. Microbiol. 78, 5501-5510. doi: 10.1128/AEM.01084-12

Takach, J. E., and Young, C. A. (2014). Alkaloid genotype diversity of tall fescue endophytes. Crop Sci. 54, 667-678. doi: 10.2135/cropsci2013.06.0423

Tanaka, A., Tapper, B. A., Popay, A., Parker, E. J., and Scott, B. (2005). A symbiosis expressed non-ribosomal peptide synthetase from a mutualistic fungal endophyte of perennial ryegrass confers protection to the symbiotum from insect herbivory. Mol. Microbiol. 57, 1036-1050. doi: 10.1111/j.13652958.2005.04747.x

Tsai, H. F., Liu, J. S., Staben, C., Christensen, M. J., Latch, G. C., Siegel, M. R., et al. (1994). Evolutionary diversification of fungal endophytes of tall fescue grass by 
hybridization with Epichloë species. Proc. Natl. Acad. Sci. U.S.A. 91, 2542-2546. doi: 10.1073/pnas.91.7.2542

Wang, J., Machado, C., Panaccione, D. G., Tsai, H. F., and Schardl, C. L. (2004). The determinant step in ergot alkaloid biosynthesis by an endophyte of perennial ryegrass. Fungal Genet. Biol. 41, 189-198. doi: 10.1016/j.fgb.2003. 10.002

West, C., Izekor, E., Turner, K., and Elmi, A. (1993). Endophyte effects on growth and persistence of tall fescue along a water-supply gradient. Agron. J. 85, 264-270. doi: 10.2134/agronj1993.000219620085000 20019x

Yates, S. (1971). Toxin-producing fungi from fescue pasture. Microb. Toxins 7 , 191-206. doi: 10.1016/B978-0-12-046507-1.50012-4

Young, C. A., Felitti, S., Shields, K., Spangenberg, G., Johnson, R. D., Bryan, G. T., et al. (2006). A complex gene cluster for indole-diterpene biosynthesis in the grass endophyte Neotyphodium lolii. Fungal Genet. Biol. 43, 679-693. doi: 10.1016/j.fgb.2006.04.004

Young, C. A., Hume, D. E., and McCulley, R. L. (2013). Forages and pastures symposium: fungal endophytes of tall fescue and perennial ryegrass: pasture friend or foe? J. Anim. Sci. 91, 2379-2394. doi: 10.2527/jas. 2012-5951

Young, C. A., Tapper, B. A., May, K., Moon, C. D., Schardl, C. L., and Scott, B. (2009). Indole-diterpene biosynthetic capability of Epichloë endophytes as predicted by ltm gene analysis. Appl. Environ. Microbiol. 75, 2200-2211. doi: 10.1128/AEM.00953-08

Conflict of Interest Statement: The authors declare that the research was conducted in the absence of any commercial or financial relationships that could be construed as a potential conflict of interest.

Received: 29 July 2014; accepted: 14 October 2014; published online: 04 November 2014.

Citation: Young CA, Charlton ND, Takach JE, Swoboda GA, Trammell MA, Huhman DV and Hopkins AA (2014) Characterization of Epichloë coenophiala within the US: are all tall fescue endophytes created equal? Front. Chem. 2:95. doi: 10.3389/fchem. 2014.00095

This article was submitted to Chemical Biology, a section of the journal Frontiers in Chemistry.

Copyright () 2014 Young, Charlton, Takach, Swoboda, Trammell, Huhman and Hopkins. This is an open-access article distributed under the terms of the Creative Commons Attribution License (CC BY). The use, distribution or reproduction in other forums is permitted, provided the original author(s) or licensor are credited and that the original publication in this journal is cited, in accordance with accepted academic practice. No use, distribution or reproduction is permitted which does not comply with these terms. 